\title{
Assessment of Continuous Oil and Gas Resources in the San Jorge Basin Province, Argentina, 2017
}

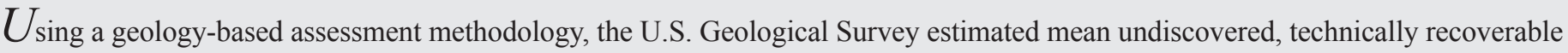
resources of 78 million barrels of oil and 8.9 trillion cubic feet of gas in the San Jorge Basin Province, Argentina.

\section{Introduction}

The U.S. Geological Survey (USGS) completed an assessment of undiscovered, technically recoverable continuous oil and gas resources within the San Jorge Basin Province of Argentina (fig. 1). The structural configuration of the San Jorge Basin is the result of several phases of extension beginning in the Permian-Triassic related to the initial oblique rifting of South America from Africa and ending with final continental breakup and separation in late Early Cretaceous (Macdonald and others, 2003). Episodes of extension formed a series of east-west to northwest-southeast trending normal faults that define a deep central basin with shallower basin margins to the north and south (Fitzgerald and others, 1990; Sylwan, 2001; Foix and others, 2012; Paredes and others, 2013). Sediments deposited during the Late Jurassic-Early Cretaceous extension and thermal sag are mainly nonmarine fluvial and lacustrine sandstones, siltstones, and shales that include the principal petroleum source rocks in the province. Neogene compression related to Andean subduction inverted some extensional structures in a narrow band in the basin forming the nearly north-south trending San Bernardo fold belt (fig. 1).

\section{Total Petroleum Systems and Assessment Units}

For the San Jorge Basin Province, the USGS defined two total petroleum systems (TPSs): the D-129 Lacustrine TPS and the Callovian-Aptian Lacustrine Composite TPS (Rodriguez and Littke, 2001; Legarreta and Villar, 2011). The D-129 Lacustrine TPS was defined by the presence of thermally mature Hauterivian-Aptian organic-rich lacustrine shales of the D-129 Formation. These shales have total organic carbon values as much as 4 weight percent and a maximum thickness of 2,000 meters. Within this TPS are the D-129 Lacustrine Shale Oil Assessment Unit (AU) and the D-129 Lacustrine Shale Gas AU. The geologic model for these AUs is for recoverable oil or gas to have been retained within the D-129 Formation lacustrine shales following petroleum migration into conventional traps.

The Callovian-Aptian Lacustrine Composite TPS was defined to account for potential tight-gas resources sourced by lacustrine organic-rich shales of the Callovian-Berriasian Aguada Bandera Formation and lacustrine shales of the Hauterivian-Aptian D-129 Formation (Legarreta and Villar, 2011). In this composite TPS, total organic carbon values are as much as 4 weight percent, and maximum thickness of the shale interval is about 600 meters. The Eastern San Jorge Tight Gas AU and the Western San Jorge Tight Gas AU are within this TPS. The geologic model is for recoverable gas to have been trapped in a low-permeability matrix of alluvial, fluvial, and marginal lacustrine sandstones of the Neocomian synrift Matasiete Formation and in overlying sandstones of the Mina del Carmen Formation.

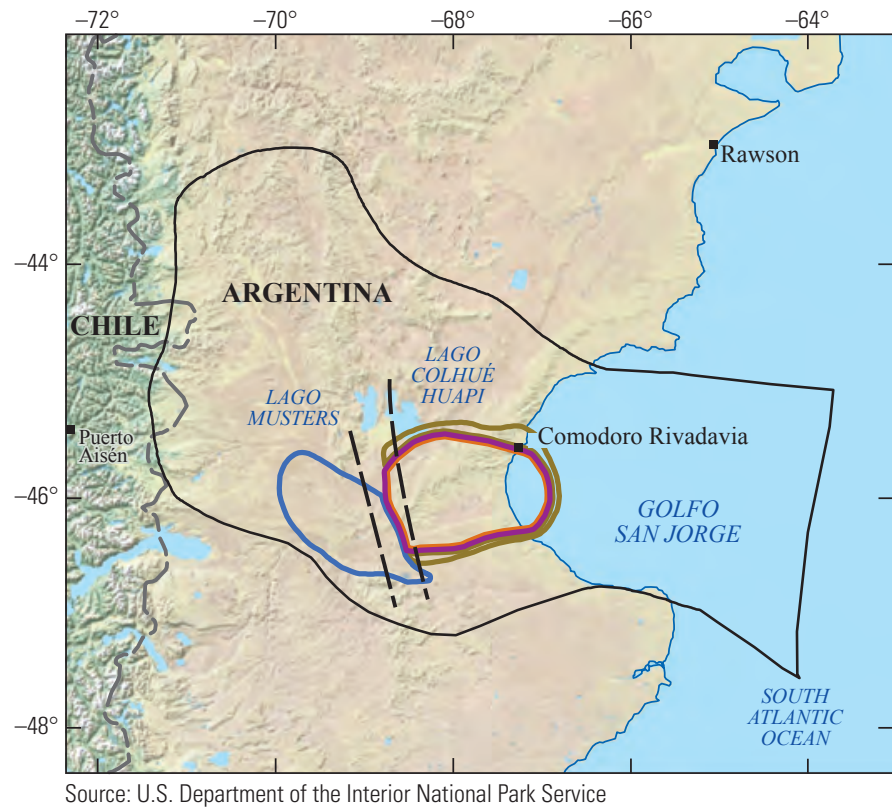

$$
\begin{array}{ccc}
0 & 50 & 100 \text { MILES } \\
0 & 50 & 1 \\
1 & 100 \text { KILOMETERS }
\end{array}
$$

\section{EXPLANATION}
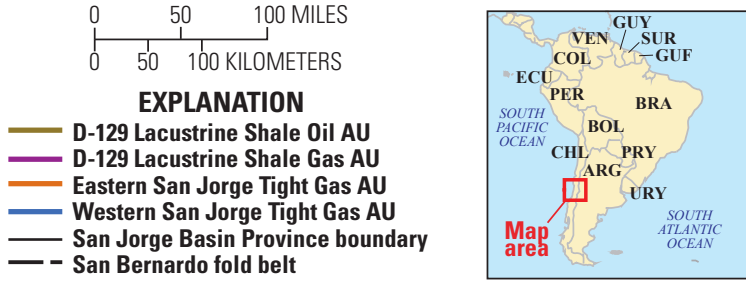

Figure 1. Location of the San Jorge Basin Province, Argentina, and the four assessment units (AUs) defined in this study.

Assessment input data for four continuous AUs are shown in table 1. Well drainage areas, estimated ultimate recoveries, and success ratios were guided by U.S. shale-oil, shale-gas, and tightgas analogs.

\section{Undiscovered Resources Summary}

The USGS quantitatively assessed undiscovered, technically recoverable continuous oil and gas resources within the San Jorge Basin Province (table 2). The estimated mean totals for continuous oil and gas resources are 78 million barrels of oil (MMBO) with an F95-F5 range from 17 to $180 \mathrm{MMBO} ; 8,893$ billion cubic feet of gas (BCFG), or 8.9 trillion cubic feet of gas, with an F95-F5 range from 1,802 to 20,869 BCFG; and 67 million barrels of natural gas liquids (MMBNGL) with an F95-F5 range from 13 to 165 MMBNGL.

For the mean total continuous gas resources of $8,893 \mathrm{BCFG}$, $3,440 \mathrm{BCFG}$ (39 percent) are estimated to be shale-gas resources, and 5,453 $\mathrm{BCFG}$ (61 percent) are estimated to be tightgas resources. 
Table 1. Key assessment input data for four assessment units in the San Jorge Basin Province, Argentina.

[AU, assessment unit; \%, percent; EUR, estimated ultimate recovery per well; MMBO, million barrels of oil; BCFG, billion cubic feet of gas. EUR, well drainage area, and success ratios are defined partly using U.S. shale-oil analogs. The average EUR input is the minimum, median, maximum, and calculated mean. Shading indicates not applicable]

\begin{tabular}{|c|c|c|c|c|c|c|c|c|}
\hline \multirow{2}{*}{ Assessment input data } & \multicolumn{4}{|c|}{ D-129 Lacustrine Shale Oil AU } & \multicolumn{4}{|c|}{ D-129 Lacustrine Shale Gas AU } \\
\hline & Minimum & Mode & Maximum & Calculated mean & Minimum & Mode & Maximum & Calculated mean \\
\hline Potential production area of AU (acres) & 1,600 & 266,500 & 533,000 & 267,033 & 1,200 & 846,600 & $2,822,000$ & $1,223,267$ \\
\hline Average drainage area of wells (acres) & 80 & 160 & 240 & 160 & 40 & 80 & 120 & 80 \\
\hline Success ratios (\%) & 10 & 50 & 90 & 50 & 10 & 50 & 90 & 50 \\
\hline Average EUR (MMBO, oil; BCFG, gas) & 0.04 & 0.08 & 0.3 & 0.092 & 0.1 & 0.4 & 1.2 & 0.441 \\
\hline AU probability & 1.0 & & & & 1.0 & & & \\
\hline \multirow{2}{*}{ Assessment input data } & \multicolumn{4}{|c|}{ Eastern San Jorge Tight Gas AU } & \multicolumn{4}{|c|}{ Western San Jorge Tight Gas AU } \\
\hline & Minimum & Mode & Maximum & Calculated mean & Minimum & Mode & Maximum & Calculated mean \\
\hline Potential production area of AU (acres) & 800 & $1,411,000$ & $2,822,000$ & $1,411,267$ & 800 & 554,500 & $1,109,000$ & 554,767 \\
\hline Average drainage area of wells (acres) & 40 & 80 & 120 & 80 & 40 & 80 & 120 & 80 \\
\hline Success ratios (\%) & 10 & 50 & 90 & 50 & 10 & 50 & 90 & 50 \\
\hline Average EUR (BCFG, gas) & 0.1 & 0.4 & 1.2 & 0.441 & 0.1 & 0.4 & 1.2 & 0.441 \\
\hline AU probability & 1.0 & & & & 1.0 & & & \\
\hline
\end{tabular}

Table 2. Assessment results for four continuous assessment units in the San Jorge Basin Province, Argentina.

[MMBO, million barrels of oil; BCFG, billion cubic feet of gas; NGL, natural gas liquids; MMBNGL, million barrels of natural gas liquids. Results shown are fully risked estimates. For gas accumulations, all liquids are included in the NGL category. F95 represents a 95-percent chance of at least the amount tabulated; other fractiles are defined similarly. Fractiles are additive under the assumption of perfect positive correlation. Shading indicates not applicable]

\begin{tabular}{|c|c|c|c|c|c|c|c|c|c|c|c|c|c|c|}
\hline \multirow{3}{*}{$\begin{array}{l}\text { Total petroleum systems } \\
\text { and assessment units (AUs) }\end{array}$} & \multirow{3}{*}{$\begin{array}{c}\text { AU } \\
\text { prob- } \\
\text { ability }\end{array}$} & \multirow{3}{*}{$\begin{array}{c}\text { Accu- } \\
\text { mulation } \\
\text { type }\end{array}$} & \multicolumn{12}{|c|}{ Total undiscovered resources } \\
\hline & & & \multicolumn{4}{|c|}{ Oil (MMBO) } & \multicolumn{4}{|c|}{ Gas (BCFG) } & \multicolumn{4}{|c|}{ NGL (MMBNGL) } \\
\hline & & & F95 & F50 & F5 & Mean & F95 & F50 & F5 & Mean & F95 & F50 & F5 & Mean \\
\hline \multicolumn{15}{|c|}{ D-129 Lacustrine Total Petroleum System } \\
\hline D-129 Lacustrine Shale Oil AU & 1.0 & Oil & 17 & 66 & 180 & 78 & 12 & 49 & 137 & 58 & 0 & 1 & 2 & 1 \\
\hline D-129 Lacustrine Shale Gas AU & 1.0 & Gas & & & & & 643 & 2,760 & 8,188 & 3,382 & 6 & 27 & 85 & 34 \\
\hline \multicolumn{15}{|c|}{ Callovian-Aptian Lacustrine Composite Total Petroleum System } \\
\hline Eastern San Jorge Tight Gas AU & 1.0 & Gas & & & & & 825 & 3,339 & 9,011 & 3,921 & 5 & 20 & 56 & 23 \\
\hline Western San Jorge Tight Gas AU & 1.0 & Gas & & & & & 322 & 1,299 & 3,533 & 1,532 & 2 & 8 & 22 & 9 \\
\hline Total undiscovered continuous resources & & & 17 & 66 & 180 & 78 & 1,802 & 7,447 & 20,869 & 8,893 & 13 & 56 & 165 & 67 \\
\hline
\end{tabular}

\section{References Cited}

Fitzgerald, M.G.; Mitchum, R.M., Jr.; Uliana, M.A.; and Biddle, K.T., 1990, Evolution of the San Jorge Basin, Argentina: American Association of Petroleum Geologists Bulletin, v. 74, no. 6, p. 879-920.

Foix, Nicolás, Paredes, J.M., and Giacosa, R.E., 2012, Upper Cretaceous-Paleocene extensional phase in the Golfo San Jorge basin (Argentina) - Growth fault model, paleoseismicity and paleostress analysis: Journal of South American Earth Sciences, v. 33, no. 1, p. $110-118$.

Legarreta, Leonardo, and Villar, H.J., 2011, Geological and geochemical keys of the potential shale resources, Argentina basins: American Association of Petroleum Geologists, Search and Discovery Article No. 80196, November 7, 2011, 21 p., accessed March 21, 2017, at http://www.searchanddiscovery.com/pdfz/documents/2011/80196legarreta/ndx_legarreta.pdf.html.

Macdonald, David; Gomez-Perez, Irene; Franzese, Juan; Spalletti, Luis; Lawver, Lawrence; Gahagan, Lisa; Dalziel, Ian; Thomas, Chris; Trewin, Nigel; Hole, Malcolm; and Paton, Douglas, 2003, Mesozoic break-up of SW Gondwana-Implications for regional hydrocarbon potential of the southern South Atlantic: Marine and Petroleum Geology, v. 20, nos. 3-4, p. 287-308.

Paredes, J.M., Plazibat, S.G., Crovetto, Carolina, Stein, Julián, Cayo, Eric, and Schiuma, Ariel, 2013, Fault kinematics and depocenter evolution of oil-bearing, continental successions of the Mina del Carmen Formation (Albian) in the Golfo San Jorge Basin, Argentina: Journal of South American Earth Sciences, v. 46, p. 63-79.

Rodriguez, J.F.R., and Littke, Ralf, 2001, Petroleum generation and accumulation in the Golfo San Jorge Basin, Argentina-A Basin modeling study: Marine and Petroleum Geology, v. 18, no. 9, p. 995-1028.

Sylwan, C.A., 2001, Geology of the Golfo San Jorge Basin, Argentina: Journal of Iberian Geology, v. 27, p. 123-157.

\section{For More Information}

Assessment results also are available at the USGS Energy Resources Program website at https://energy.usgs.gov.

\section{San Jorge Basin Province Assessment Team}

Christopher J. Schenk, Tracey J. Mercier, Sarah J. Hawkins, Marilyn E. Tennyson, Kristen R. Marra, Thomas M. Finn, Phuong A. Le, Michael E. Brownfield, Heidi M. Leathers-Miller, and Cheryl A. Woodall 